\title{
ANALISIS SWOT DALAM MENENTUKAN STRATEGI PEMASARAN KOSMETIK WARDAH DI KOTA BENGKULU
}

\author{
Herlin $^{1}$, Yesi Noti Anggraini' ${ }^{2}$ Rina Trisna Yanti ${ }^{3}$ \\ ${ }^{1,2 \& 3}$ Universitas Dehasen Bengkulu

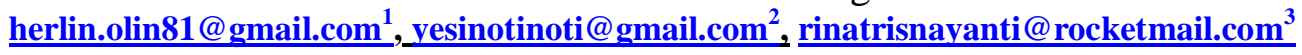

\begin{abstract}
The purpose of this research is to find out Wardah cosmetic product marketing strategy in Eljhon 2 Bengkulu. The analytical method used in this study is SWOT analysis (Strength, Weaknesses, Opportunities and Threats), with a total sample of 33 respondents. Based on the results of the SWOT analysis using IFAS and EFAS analysis, it is located in the coordinates of the score (20.31: 1.16) and is in quadrant 1 with greater strength and opportunity than weaknesses and threats which support aggressive strategies, where strengths (strengths) worth 28.62 weaknesses worth 18.31 opportunities worth 17.27 and threats valued at 16.11. Quadrant 1, this is a very profitable position so that it can take full advantage of the company's strengths and opportunities.
\end{abstract}

Keyword : SWOT Analysis (Strength, Weaknesses, Opportunities and Threats)

\section{PENDAHULUAN}

Wardah merupakan salah satu merek kecantikan yang berlabel halal yang merupakan salah satu produk yang diluncurkan oleh PT. Paragon Tecknology and Innovation. Wardah berkembang menjadi salah satu merek kosmetik asli dalam negeri yang terbesar di Indonesia dan mampu menjadi kompetitor produk asing. Konsistensi dari konsep yang diusung Wardah selalu dipertahankan sehingga konsumen yang memang tertarik dan mendapatkan apa yang diinginkannya dan akan setia menggunakannya. Konsep yang mengusung kosmetika "Halal dan Islami", Wardah tidak tergoyahkan dan konsistensi dijalani oleh perusahaan dalam pembuatan maupun pemasaran. Sehingga dalam pandangan konsumen ketika mendegar kata kosmetika alami maka akan teringat kosmetik Wardah.

PT. Paragon Tecknology and Innovation merupakan salah satu perusahaan dagang yang bergerak di dibidang kosmetik, salah satu produk yang menjadi trend dikalangan ibu-ibu dan remaja adalah kosmetika kecantikan yang berlabel halal. Selama ini PT. Paragon Tecknology and Innovation mengembankan pemasaran dengan cara melihat pergerakan pasar, pengembangan support tim, pelatihan, menciptakan peluang bisnis baru dan membangung networking. Wardah hidup dari satu cerita wanita Indonesia ke cerita wanita yang lain, sehingga rekomendasi dari mulut ke mulut ini merupakan bukti paling signifikan bahwa kualitas tak bisa berjalan sendiri tanpa ada pemasaran yang baik, sehingga diperlukan strategistrategi yang dapat meningkatkan penjualan kosmetik merek Wardah yang ada di Bengkulu. 


\section{TINJAUAN PUSTAKA \\ Manajemen Strategi}

Strategi merupakan alat untuk mencapai tujuan perusahaan dalam kaitannya dengan tujuan jangka panjang, program tindak lanjut serta prioritas alokasi sumber daya. Kata strategi berasal dari bahasa Yunani "strategia" yang diartikan sebagai "the art of the general" atau seni seorang panglima yang biasanya digunakan dalam peperangan (Rangkuti, 2017:4). Menurut Fahmi (2015:2), adapun ruang lingkup manajemen strategis adalah :

1. Mengkaji dan menganalisis dampak penerapan manajemen strategis kepada internal perusahaan khususnya pada perbaikan yang bersifat berkelanjutan.

2. Menempatkan konstruksi manajemen strategis sebagai dasar pondasi perusahaan dalam memutuskan setiap keputusan, khususnya keputusan yang berhubungan dengan profit dan ekspansi perusahaan.

3. Menjadikan ilmu manajemen strategis sebagai base thinking dalam membangun berbagai rencan termasuk rencana produksi, pemasaran, personalia dan keuangan.

Menurut Rangkuti (2017:7), pada prinsipnya strategi dapat dikelompokkan berdsarkan tiga tipe strategi yaitu :

a. Strategi manajemen, strategi ini meliputi strategi yang dapat dilakukan oleh manajemen dengan orientasi pengembangan strategi secara makro.

b. Strategi investasi, strategi ini merupakan kegiatan yang berorientasi pada investasi.

c. Strategi bisnis, strategi bisnis ini sering juga disebut strategi bisnis secara fungsional, karena strategi ini berorientasi pada fungsi-fungsi kegiatan manajemen

\section{Pengertian Pemasaran}

David (2011:219), pemasaran dapat dideskripsikan sebagai proses mendefinisikan, mengantisipasi, menciptakan, memenuhi kebutuhan dan keinginan konsumen atas barang dan jasa. Assauri (2011:80), konsep pemasaran dibuat dengan menggunakan tiga faktor dasar yaitu:

1. Saluran perencanaan dan kegiatan perusahaan harus berorientasi pada pasar konsumen.

2. Volume penjualan yang menguntungkan harus menjadi tujuan perusahaan, dan bukannya volume untuk kepentingan volume itu sendiri.

3. Seluruh kegiatan pemasaran dalam perusahaan harus dikoordinasikan dan diintegrasikan secara organisasi.

Menurut Rangkuti (2017:102), unsur-unsur utama pemasaran diklasifikasikan menjadi tiga unsur utama yaitu :

1. Unsur strategi persaingan

a. Segmentasi pasar, adalah tindakan mengidentifikasikan dan membentuk kelompok pembeli atau konsumen secara terpisah, masing-masing segmen konsumen memiliki karakteristik, kebutuhan produk dan bauran pemasaran tersendiri. 
b. Targeting, adalah suatu tindakan memilih satu atau lebih segmen pasar yang akan dimasuki.

c. Positioning, adalah penetapan posisi pasar. Tujuannya adalah untuk membangun dan mengkomunikasikan keunggulan bersaing produk yang ada di pasar ke dalam benak konsumen

2. Unsur taktik pemasaran

a. Deferensiasi, yang berkaitan dengan cara membangun strategi pemasaran dalam berbgai aspek perusahaan.

b. Bauran pemasaran, yang berkaitan dengan kegiatan-kegiatan mengenai produk, harga, promosi dan tempat.

3. Unsur nilai pemasaran

a. Merek (Brand), yaitu nilai yang berkaitan dengan nama tau nilai yang dimiliki dan melekat pada suatu perusahaan.

b. Pelayanan (Service), yaitu nilai yang berkaitan dengan pemberian jasa pelayanan kepada konsumen.

c. Proses, yaitu nilai yang berkaitan dengan prinsip perusahaan untuk membuat setiap karyawan terlibat dan memiliki rasa tanggung jawab dalam prosen memuaskan konsumen, baik secara langsung maupun secara tidak langsung.

\section{Perencanaan Strategi Pemasaran}

Menurut Amirullah (2015:4), perumusan strategi merupakan proses penyusunan langkah-langkah ke depan yang dimaksudkan untuk membangun visi dan misi organisasi, menetapkan tujuan strategis dan keuangan perusahaan, serta merancang strategi untuk mencapai tujuan tersebut dalam rangka menyediakan customer value terbaik. David (2011:176), ada beberapa jenis strategi yang dikembangkan oleh berbagai ilmuan diantaranya :

1. Strategi Integrasi

2. Strategi Intensif

3. Strategi Diversifikasi

4. Strategi Defensif

5. Strategi Umum

\section{Analisis SWOT}

Fahmi (2013:352), SWOT merupakan singkatan dari Strengths, Opportunities, Weaknesses dan Threats adalah sebuah model dalam menganalisis suatu organisasi yang berorientasi pada profit dan non profit dengan tujuan utama untuk mengetahui kondisi organisasi tersebut secara lebih komprehensif. Rangkuti (2017:19), analisis SWOT adalah identifikasi berbagai faktor secara sistematis untuk merumuskan strategi perusahaan, analisis ini didasarkan pada logika yang dapat memaksimalkan kekuatan (Strenghts) dan peluang (Opportunities), namun secara bersamaan dapat meminimalkan kelemahan (Weaknesses) dan ancaman (Threats).

a. Strengths (kekuatan) adalah sebuah kekuatan normal yang dimiliki oleh perusahaan atau kemampuan yang dapat digunakan sebagai dasar untuk mengembangkan perusahaan. 
b. Weaknesses (kelemahan) adalah keterbatasan dan kekurangan internal perusahaan dalam finansial, sumber daya manusia, penerapan teknologi sehingga menghambat perkembangan kemajuan perusahaan dalam bersaing.

c. Opportunities (peluang) adalah situasi penting yang mengun-tungkan dari luar perusahaan.

d. Threats (ancaman) adalah kondisi yang tidak menguntungkan bagi perusahaan dari luar perusahaan (eksternal) sehingga berdampak pada hambatan perusahaan.

Gambar 1. Diagram Analisis SWOT

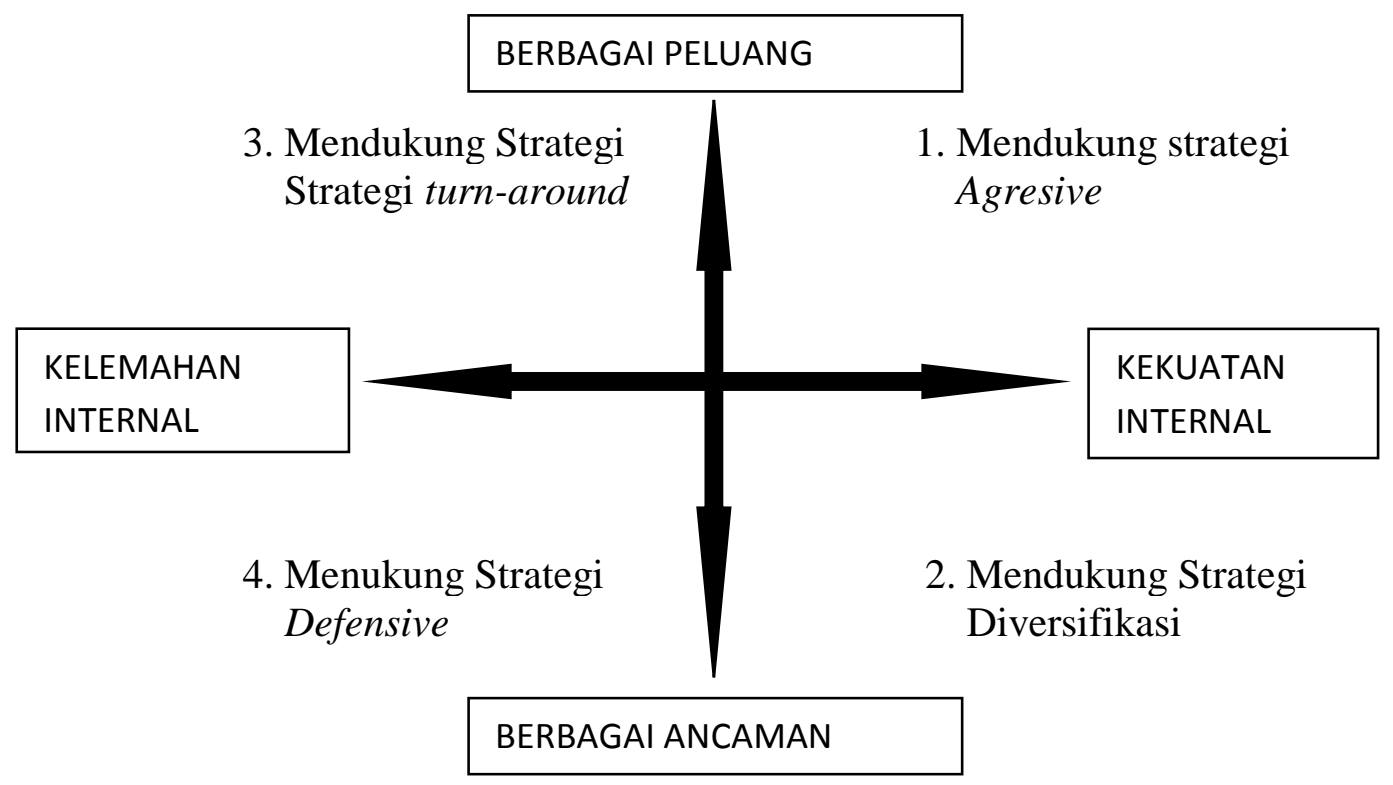

Sumber : Rangkuti (2017:20)

Keterangan :

Kuadran I : Ini merupakan situasi yang sangat menguntungkan. Perusahaan tersebut memiliki peluang dan kekuatan sehingga dapat memanfaatkan peluang yang ada. Strategi yang harus diterapkan dalam kondisi ini adalah mendukung kebijakan pertumbuhan yang agresif (growth oriented strategy).

Kuadran2 : Meskipun menghadapi berbagai ancaman, perusahaan ini masih memiliki kekuatan dari segi internal. Strategi yang harus diterapkan adalah menggunakan kekuatan untuk memanfaatkan peluang jangka panjang dengan cara strategi diversifikasi (produk/pasar).

Kuadran 3 : Perusahaan menghadapi peluang pasar yang sangat besar, tetapi dilain pihak ia menghadapi beberapa kendala/kelemahan internal. Kondisi bisnis pada kuadran 3, ini mirip dengan Question Mark pada BCG Matrix. Fokus strategi perusahaan ini adalah meminimalkan masalah-masalah internal perusahaan sehingga dapat merebut peluang pasar yang lebih baik. 
Kuadran 4 : Ini merupakan situasi yang sangat tidak menguntungkan, perusahaan tersebut menghadapi berbagai ancaman dan kelemahan internal.

Gambar. Matriks SWOT

\begin{tabular}{|c|c|c|}
\hline IFAS & $\begin{array}{l}\text { STRENGTHS (S) } \\
\text { Tentukan 5-10 faktor-fakor } \\
\text { kelemahan internal }\end{array}$ & 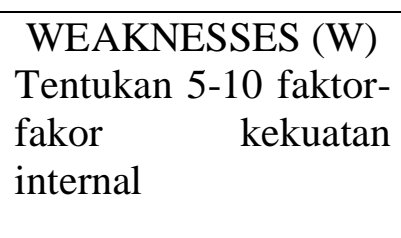 \\
\hline OPPORTUNITIES $(O)$ & STRATEGI SO & STRATEGI WO \\
\hline $\begin{array}{l}\text { Tentukan } \quad 5-10 \text { faktor } \\
\text { peluang eksternal }\end{array}$ & $\begin{array}{lr}\text { Ciptakan strategi } & \text { yang } \\
\text { menggunakan } & \text { semua } \\
\text { kekuatan } & \text { untuk } \\
\text { memanfaatkan peluang } & \end{array}$ & $\begin{array}{l}\text { Ciptakan strategi yang } \\
\text { meminimalkan } \\
\text { kelemahan untuk } \\
\text { memanfaatkan } \\
\text { peluang }\end{array}$ \\
\hline $\begin{array}{l}\text { THREATHS }(\mathrm{T}) \\
\text { Tentukan 5-10 faktor } \\
\text { ancaman eksternal }\end{array}$ & \begin{tabular}{l}
\multicolumn{2}{c}{ STRATEGI ST } \\
Ciptakan strategi yang \\
menggunakan kekuatan \\
untuk \\
mengatasi ancaman
\end{tabular} & \begin{tabular}{l}
\multicolumn{1}{c}{ STRATEGI WT } \\
Ciptakan strategi yang \\
meminimalkan \\
kelemahan dan \\
menghindari ancaman
\end{tabular} \\
\hline
\end{tabular}

Sumber : Rangkuti (2017:83).

\section{METODE PENELITIAN}

\section{Jenis Penelitian}

Jenis penelitian ini adalah deskriftif kualitatif. Menurut Sugiyono (2017:367), deskriptif kualitatif adalah analisis data yang dilakukan dengan menggorganisasikan data, menjabarkannya ke dalam unit-unit, malukan sintesis, menysusun ke dalam pola, memilih mana yang penting dan yang akan dipelajari dan membuat kesimpulan yang dapat diceritakan kepada orang lain.

\section{Metode Pengambilan sampel}

Populasi adalah wilayah generalisasi yang terdiri dari objek/subjek yang mempunayi kualitas dan karekteristik tertentu yang diterapkan oleh peneliti untuk dipelajari dan kemudian ditarik kesimpulan, Sedangkan sampel adalah bagian dari jumlah karakteristik yang dimilki oleh populasi (Sugiyono, 2017:135). Metode pengambilan sampel dalam penelitian ini menggunakan teknik penentuan sampel berdasarkan kebetulan (Accidental Sampling), artinya siapa saja pelanggan yang secara kebetuhan bertemu dengan peneliti pada saat penelitian (Sugiyono, 2017:135). Adapun sampel dalam penelitian ini adalah :

Tabel 3.1. Sampel penelitian

\begin{tabular}{|l|l|c|l|}
\hline No & Uraian & Jumlah & Keterangan \\
\hline \multicolumn{2}{|l|}{ Responden Internal } & & \\
\hline 1 & Pimpinan & 1 & orang \\
\hline 2 & Karyawan & 2 & orang \\
\hline
\end{tabular}




\begin{tabular}{|l|l|c|l|}
\hline No & Uraian & Jumlah & Keterangan \\
\hline \multicolumn{2}{|l|}{ Responden Eksternal } & & \\
\hline 3 & Konsumen dan & 10 & orang \\
\hline 4 & $\begin{array}{l}\text { Pemilik } \\
\text { karyawan Eljhon 2 } \\
\text { Bengkulu }\end{array}$ & 33 & orang \\
\hline & Jumlah & & \\
\hline
\end{tabular}

\section{Metode Pengumpulan Data}

Metode pengumpulan dalam peneltian ini menggunakan data primer yang diperoleh langsung dari tempat penelitian dengan cara menyebarkan kuesioner kepada, dengan penilaian menggunakan skala likert.

\section{Metode Analisis}

Metode analisis yang digunakan dalam penelitian ini adalah analisis SWOT Untuk menghitung nilai Bobot, rating dan skor pada tabel faktor strategi internal dan eksternal dengan menggunakan teknik skala (Fahmi, 2015:262) sebagai berikut :

Bobot nilai

$$
\begin{array}{ll}
1,00 & =\text { Sangat penting } \\
0,75 & =\text { Penting } \\
0,50 & =\text { Standar } \\
0,25 & =\text { Tidak penting } \\
0,10 & =\text { Sangat tidak penting }
\end{array}
$$

Rating nilai

$$
\begin{aligned}
& 5=\text { Sangat baik } \\
& 4=\text { Baik } \\
& 3=\text { Netral (standar) } \\
& \text { 2= Tidak baik } \\
& \text { 1= Sangat Tidak baik }
\end{aligned}
$$

Skor nilai

Di mana:

$$
\mathrm{SN}=\mathrm{BN} \times \mathrm{RN}
$$

$\mathrm{SN}=$ skor nilai

$\mathrm{BN}=$ Bobot Nilai

$\mathrm{RN}=$ Rating Nilai

\section{Menghitung bobot nilai dan rating dalam matrik SWOT.}

1. Langkah pertama adalah menentukan nilai bobot, nilai rating dan skor. Bobot ditentukan berdasarkan tingkat kepentingan atau penanganan dengan skala 0,10 sampai $1,00(0,10=$ Sangat Tidak Penting dan 1,00 = Sangat Penting $)$.

2. Langkah kedua, menjumlahkan bobot kekuatan dan bobot kelemahan, kemudian dihitung bobot relatif untuk masing-masing indikator yang terdapat kekuatan dan kelemahan, sehingga total nilai bobot tersebut menjadi 1 atau $100 \%$. Dengan cara yang sama dihitung nilai bobot dan bobot relatif untuk peluang dan ancaman.

3. Langkah ketiga, menentukan nilai Rating. Nilai rating analisis kita terhadap kemungkinan yang akan terjadi dalam jangka pendek (misal satu tahun kedepan).

4. Langkah ke empat, menghitung nilai skor yang diperoleh dari hasil nilai bobot dikali nilai rating. Nilai skor faktor internal yaitu semakin nilai mendekati 1 semakin banyak kelemahan internal perusahaan dibandingkan kekuatannya dan 
semakin nilainya mendekati 5, semakin banyak kekuatannya dibandingkatn kelemahannya, sedangkan faktor eksternal semakin total nilai skor mendekati nilai 1 maka semakin banyak ancamannya dibandingkan peluang dan bila total nilai skor mendekati 5 maka semakin banyak peluang dari pada ancaman.

5. Langkah ke lima, yaitu mengggabungkan kedua nilai faktor internal dan faktor eksternal kamudian dimasukkan dalam matriks, sehingga kita mengetahui posisi pesaing yang akan terjadi pada korporat, unit bisnis, maupun produk yang kita analisis, berdasarkan posisi ini kita dapat menentukan strategi yang tepat untuk strategi pemasaran kedepan.

Tabel 3.3 Format analisis SWOT untuk faktor eksternal dan internal

\begin{tabular}{|c|c|c|c|c|}
\hline No & Uraian & Bobot & Rating & skor \\
\hline \multirow[t]{3}{*}{ I } & Strengths & & & \\
\hline & $1 \ldots \ldots \ldots \ldots \ldots \ldots \ldots \ldots$ & Nilai & Nilai & Nilai \\
\hline & $2 \ldots \ldots \ldots \ldots \ldots \ldots \ldots \ldots$ & Nilai & Nilai & Nilai \\
\hline \multirow[t]{3}{*}{ II } & Weaknessess & & & \\
\hline & $1 \ldots \ldots \ldots \ldots \ldots \ldots \ldots \ldots$ & Nilai & Nilai & Nilai \\
\hline & $2 \ldots \ldots \ldots \ldots \ldots \ldots \ldots \ldots$ & Nilai & Nilai & Nilai \\
\hline \multirow[t]{3}{*}{ III } & Opportunities & & & \\
\hline & $1 \ldots \ldots \ldots \ldots \ldots \ldots \ldots \ldots$ & Nilai & Nilai & Nilai \\
\hline & $2 \ldots \ldots \ldots \ldots \ldots \ldots \ldots \ldots$ & Nilai & Nilai & Nilai \\
\hline \multirow[t]{3}{*}{ IV } & Threats & & & \\
\hline & $1 \ldots \ldots \ldots \ldots \ldots \ldots \ldots \ldots$ & Nilai & Nilai & Nilai \\
\hline & 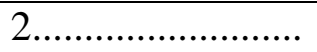 & Nilai & Nilai & Nilai \\
\hline
\end{tabular}

Sumber : Fahmi (2015:263)

Diagram Analisis SWOT :

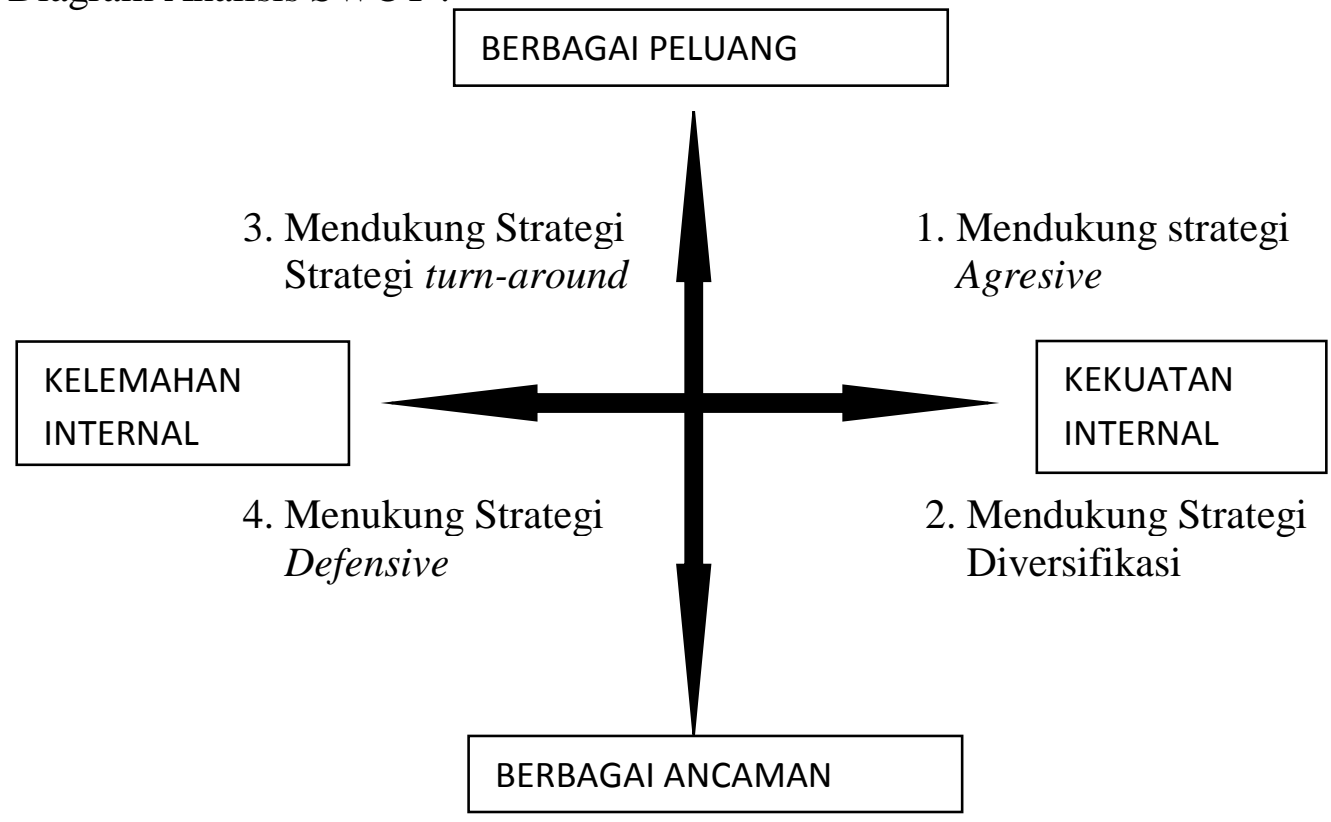

Sumber : Rangkuti (2017:20) 
Keterangan :

Kuadran I : ini merupakan situasi yang sangat menguntungkan. Perusahaan tersebut memiliki peluang dan kekuatan sehingga dapat memanfaatkan peluang yang ada. Strategi yang harus diterapkan dalam kondisi ini adalah mendukung kebijakan pertumbuhan yang agresif (growth oriented strategy).

Kuadran 2: meskipun menghadapi berbagai ancaman, perusahaan ini masih memiliki kekuatan dari segi internal. Strategi yang harus diterapkan adalah menggunakan kekuatan untuk memanfaatkan peluang jangka panjang dengan cara strategi diversifikasi (produk/pasar).

Kuadran 3 : Perusahaan menghadapi peluang pasara yang sangat besar, tetapi dilain pihak ia menghadapi beberapa kendala/kelemahan internal. Kondisi bisnis pada kuadran 3, ini mirip dengan Question Mark pada $B C G$ Matrix. Fokus strategi perusahaan ini adalah meminimalkan masalah-masalah internal perusahaan sehingga dapat merebut peluang pasar yang lebih baik.

Kuadran 4 : ini merupakan situasi yang sangat tidak menguntungkan, perusahaan tersebut menghadapi berbagai ancaman dan kelemahan internal.

Matrix SWOT

\begin{tabular}{|c|c|c|}
\hline IFAS & $\begin{array}{l}\text { STRENGTHS (S) } \\
\text { Tentukan 5-10 faktor-fakor } \\
\text { kelemahan internal }\end{array}$ & $\begin{array}{l}\text { WEAKNESSES }(\mathrm{W}) \\
\text { Tentukan 5-10 faktor- } \\
\text { fakor kekuatan internal }\end{array}$ \\
\hline & SO & iI WO \\
\hline $\begin{array}{l}\text { Tentukan 5-10 faktor } \\
\text { peluang eksternal }\end{array}$ & $\begin{array}{lr}\text { Ciptakan strategi } & \text { yang } \\
\text { menggunakan } & \text { semua } \\
\text { kekuatan } & \text { untuk } \\
\text { memanfaatkan peluang }\end{array}$ & $\begin{array}{ll}\text { Ciptakan strategi yang } \\
\text { meminimalkan } & \\
\text { kelemahan } & \text { untuk } \\
\text { memanfaatkan peluang }\end{array}$ \\
\hline & STRATEGI ST & STRATEGI WT \\
\hline $\begin{array}{l}\text { Tentukan 5-10 faktor } \\
\text { ancaman eksternal }\end{array}$ & $\begin{array}{l}\text { Ciptakan strategi yang } \\
\text { menggunakan kekuatan } \\
\text { untuk } \\
\text { mengatasi ancaman }\end{array}$ & $\begin{array}{ll}\text { Ciptakan strategi yang } \\
\text { meminimalkan } & \\
\text { kelemahan } & \text { dan } \\
\text { menghidari ancaman } & \end{array}$ \\
\hline
\end{tabular}

Sumber : Rangkuti (2017:83).

Keterangan :

a. Strategi SO

Strategi ini dibuat berdasarkan jalan pikiran perusahaan, yaitu dengan memanfaatkan seluruh kekuatan untuk merebut peluang yang sebesar-besarnya dalam memasarkan produk kosmetik wardah di Bengkulu. .

b. Strategi ST

Strategi ini adalah strategi dalam menggunakan kekuatan yang dimiliki perusahaan untuk mengatasi ancaman dalam memasarkan produk kosmetik wardah diBengkulu. .

c. Strategi WO 
Strategi ini diterapkan berdasarkan pemanfaatan peluang yang ada dengan cara meminimalkan kelemahan yang ada dalam memasarkan produk kosmetik wardah di Bengkulu. .

d. Strategi WT

Strategi ini didasarkan pada kegiatan yang bersifat defensif dan berusahan meminimalkan kelemahan yang ada serta menghindari ancaman dalam memasarkan produk kosmetik di Bengkulu.

\section{HASIL PENELITIAN DAN PEMBAHASAN}

\section{Sejarah PT. Paragon Technology and Innovation}

PT. Paragon Tecnology and Innovation berdiri pada tanggal 28 Februari 1985 dengan nama awal PT. Pusaka Tradisi Ibu (PTI). Perusahaan ini baru berganti nama menjadi PT. Paragon Tecnology and Innovation pada tahun 2011. Perusahaan ini didirikan oleh pasangat suami isteri Drs. H. Subakat Hadi, M.Sc dan Dra. Hj. Nurhayati Subakat Apt. Pada masa itu, pendiri perusahaan melihat masih ada peluang yang terbuka. PT. Paragon Tecnology and Innovation mengembangkan program marketing termasuk analisa pergerakan pasar, pengembangan support team dan pelatihan, menciptakan peluang bisnis baru dan. Business Development sendiri menaungi Beauty Promotor dan Beauty Advisor

\section{Analisis SWOT}

\section{Faktor Internal}

Dalam memasarkan kosmetik Wardah ini yang dilakukan oleh PT. Paragon Tecnology and Innovation Bengkulu perlu mengunakan strategi-strategi yang handal dengan membuat analisa yang meliputi :

1. Kekuatan (strengths)

a) Kosmetik Wardah aman dan berlabel halal

b) Harga produk Wardah sangat terjangkau

c) Mudah dicari di toko-toko/mini market

d) Memiliki jaringan pemasaran yang luas

e) Adanya pelyanan yang didukung oleh Beauty Advisor yang handal

2. Kelemahan (weaknesses)
a) Kemasan yang tidak bervariasi (sama)
b) Produk Wardah khusus untuk wanita
c) Distribusi produk yang lama
d) Produk Wardah kurang dikenal masyarakat
e) Tidak ada diskon penjualan

\section{Faktor Eksternal}

Dalam memasarkan kosmetik Wardah PT. Paragon Tecnology and Innovation Bengkulu juga menganalisa peluang (opportunity) dan ancaman (threats) guna menghadapi perkembangan dimasa yang akan datang meliputi :

1. Peluang (Opportunity)

a) Trend hijaber yang lagi meningkat

b) Gaya hidup masyarakat yang menginginkan perawatan kulit 
c) Mayoritas penduduk merupakan orang muslim

d) Memiliki kualitas produk yang baik

e) Kesejahteraan masyarakat yang semakin meningkat

2. Ancaman (Threats)
a) Banyak kosmetik lain yang harganya lebih murah
b) Mayarakat masih meragukan kualitas produk Wardah
c) Banyak salon kecantikan yang menawarkan fasilitas yang lebih lengkap
d) Rendahnya daya beli masyarakat
e) Produk Wardah kurang diminati

Perhitungan IFAS (Internal Factor Analysis Strategy)

Nilai IFAS (Internal Factor Analysis Strategy) pada responden internal sebanyak 3 orang yaitu baik untuk bobot maupun ratingnya adalah :

Tabel 4.7. Alternatif jawaban Responden terhadap IFAS

\begin{tabular}{|l|l|c|c|}
\hline No & Alternatif Jawaban & Bobot & Rating \\
\hline 1 & STS & 0,10 & 1 \\
\hline 2 & TS & 0,25 & 2 \\
\hline 3 & N & 0,50 & 3 \\
\hline 4 & S & 0,75 & 4 \\
\hline 5 & SS & 1,00 & 5 \\
\hline
\end{tabular}

Sumber : Fahmi (2011:223)

Nilai bobot pada faktor internal yaitu kekuatan dan kelemahan dengan hasil jawaban responden internal sebanyak 3 orang yang dikalkulasikan dengan nilai skala 0,00 (sangat tidak penting) dengan 1,00 (sangat penting) yaitu :

Tabel 4.8 Kekuatan (Strengths)

\begin{tabular}{|c|l|c|c|c|}
\hline No & \multicolumn{1}{|c|}{ Kekuatan (Strengths) } & Bobot & Rating & $\begin{array}{c}\text { Skor } \\
\text { (bobot x } \\
\text { Rating) }\end{array}$ \\
\hline 1 & $\begin{array}{l}\text { Kosmetik wardah aman dan } \\
\text { berlabel halal }\end{array}$ & 1 & 5 & 5 \\
\hline 2 & $\begin{array}{l}\text { Harga produk wardah sangat } \\
\text { terjangkatu }\end{array}$ & 2,42 & 3,66 & 8,86 \\
\hline 3 & $\begin{array}{l}\text { Mudah dicari di toko-toko/mini } \\
\text { market }\end{array}$ & 1,58 & 3,33 & 5,26 \\
\hline 4 & $\begin{array}{l}\text { Memiliki jaringan pemasaran yang } \\
\text { luas }\end{array}$ & 0,75 & 4 & 3 \\
\hline 5 & $\begin{array}{l}\text { Adanya pelayanan yang didukung } \\
\text { oleh Beauty Advisor yang handal }\end{array}$ & 1,50 & 4,33 & 6,50 \\
\hline & Jumlah & 7,25 & 20,32 & 28,62 \\
\hline
\end{tabular}

Sumber : Hasil penelitian dan data diolah, 2019 
Tabel 4.9. Kelemahan (Weaknesses)

\begin{tabular}{|l|l|c|c|c|}
\hline No & \multicolumn{1}{|c|}{ Kelemahan (Weaknesses) } & Bobot & $\begin{array}{c}\text { Ratin } \\
\mathrm{g}\end{array}$ & $\begin{array}{c}\text { Skor } \\
\text { (bobot } \mathrm{x} \\
\text { Rating) }\end{array}$ \\
\hline 1 & $\begin{array}{l}\text { Kemasan yang tidak bervariasi } \\
\text { (sama) }\end{array}$ & 0,53 & 1,67 & 0,86 \\
\hline 2 & $\begin{array}{l}\text { Produk wardah khusus untuk } \\
\text { wanita }\end{array}$ & 0,92 & 2,45 & 4,6 \\
\hline 3 & Dstribusi produk yang lama & 0,78 & 2 & 1,56 \\
\hline 4 & $\begin{array}{l}\text { Produk wardah kurang dikenal } \\
\text { masyarakat }\end{array}$ & 0,32 & 1,33 & 0,43 \\
\hline 5 & Tidak ada diskon penjualan & 0,53 & 1,67 & 0,86 \\
\hline & Jumlah & 3,08 & 9,12 & 8,31 \\
\hline
\end{tabular}

Sumber : Hasil penelitian dan data diolah, 2019

Nilai IFAS (Internal Factor Analysis Strategy) yang terdiri dari kekuatan (S) dan kelemahan $(W)$ menunjukkan bahwa PT. Paragon Tecnology and Innovation Bengkulu memiliki strategi pemasaran kosmetik Wardah dengan kekuatan $(S)$ dengan skor 28,62 dan kelemahan ( $W$ ) dengan skor 8,31.

\section{Perhitungan EFAS (Eksternal Factor Analisys Strategy)}

Untuk mengetahui nilai EFAS (Eksternal Factor Analisys Strategy) yang terdiri dari peluang $(\mathrm{O})$ dan ancaman (T) PT. Paragon Tecnology and Innovation Bengkulu dalam memasarkan kosmetik Wardah kepada 30 orang konsumen. Perhitungan rating menggunakan skala yaitu 1, sangat tidak setuju, 2 tidak setuju, 3 netral, 4 setuju, dan 5 sangat setuju kemudian dibagi dengan jumlah responden sebanyak 30 orang, dengan nilai skor :

Tabel 4.10. Peluang (Opportunity)

\begin{tabular}{|c|c|c|c|c|}
\hline No & Peluang (Opportunity) & Bobot & Rating & $\begin{array}{l}\text { Skor } \\
\text { (bobot } \mathrm{x} \\
\text { Rating) }\end{array}$ \\
\hline 1 & Trend hijaber yang lagi meningkat & 0,82 & 4,25 & 3,48 \\
\hline 2 & $\begin{array}{l}\text { Gaya hidup masyarakat yang } \\
\text { menginginkan perawatan kulit }\end{array}$ & 0,84 & 4,36 & 3,66 \\
\hline 3 & $\begin{array}{l}\text { Mayoritas penduduk merupakan orang } \\
\text { muslim }\end{array}$ & 0,91 & 4,63 & 4,21 \\
\hline 4 & Memiliki kualitas produk yang baik & 0,71 & 3,83 & 2,71 \\
\hline 5 & $\begin{array}{l}\text { Kesejahteraan masyarakat yang } \\
\text { semakin meningkat }\end{array}$ & 0,78 & 4,12 & 3,21 \\
\hline & Jumlah & 4,06 & 21,19 & 17,27 \\
\hline
\end{tabular}

Sumber : Hasil penelitian dan data diolah, 2019 
Tabel 4.11. Ancaman (Threats)

\begin{tabular}{|c|c|c|c|c|}
\hline No & $\begin{array}{c}\text { Uraian } \\
\text { Ancaman (Threats) }\end{array}$ & Bobot & Rating & $\begin{array}{c}\text { Skor } \\
\text { (bobot x } \\
\text { Rating) }\end{array}$ \\
\hline 1 & $\begin{array}{l}\text { Banyak kosmetik lain yang harganya } \\
\text { lebih murah }\end{array}$ & 0,81 & 4,23 & 3,43 \\
\hline 2 & $\begin{array}{l}\text { Masyarakat masih meragu-kan } \\
\text { kualitas produk wardah }\end{array}$ & 0,74 & 3,97 & 2,94 \\
\hline 3 & $\begin{array}{l}\text { Banyak salon kecantikan yang } \\
\text { menawarkan fasilitas yang lebih } \\
\text { lengkap }\end{array}$ & 0,85 & 4,40 & 3,74 \\
\hline 4 & Rendahnya daya beli masyarakat & 0,73 & 3,93 & 2,87 \\
\hline 5 & Produk wardah kurang diminati & 0,77 & 4,07 & 3,13 \\
\hline & Jumlah & 3,90 & 20,60 & 16,11 \\
\hline
\end{tabular}

Sumber : Hasil penelitian dan data diolah, 2019

Perhitungan EFAS (External Factor Analysis Strategy) yang terdiri dari peluang $(O)$ dan ancaman $(T)$ menunjukkan bahwa PT. Paragon Tecnology and Innovation Bengkulu memiliki strategi pemasaran kosmetik Wardah dengan peluang $(O)$ dengan skor 17,27 dan ancaman $(T)$ dengan skor 16,11.

\section{Diagram Analisis Swot}

Tabel 4.12. Rekapitulasi IFAS dan EFAS

\begin{tabular}{|l|c|c|c|c|}
\hline \multirow{2}{*}{ Keterangan } & \multicolumn{2}{|c|}{ IFAS } & \multicolumn{2}{c|}{ EFAS } \\
\cline { 2 - 5 } & Strengths & Weaknesses & Opportunity & Threats \\
\hline Strategi Pemasaran & 28,62 & 8,31 & 17,27 & 12,07 \\
\hline Kuadran & $28,62-8,31=20,31$ & $17,27-16,11=1,16$ \\
\hline
\end{tabular}

Sumber : Hasil penelitian dan data diolah 2019

Tabel 4.12 Analisis IFAS strategi pemasaran kosmetik Wardah PT. Paragon Tecnology and Innovation Bengkulu memiliki kekuatan $(S)$ sebesar 28,62 dan kelemahan $(W)$ sebesar 8,31 yang terletak pada kuadran 20,31. Sedangkan analisis EFAS strategi pemasaran dengan peluang $(O)$ sebesar 17,27 dan ancaman (T) sebesar 16,11 yang terletak pada kuadran 1,16. 
Gambar. Diagram Analisis SWOT

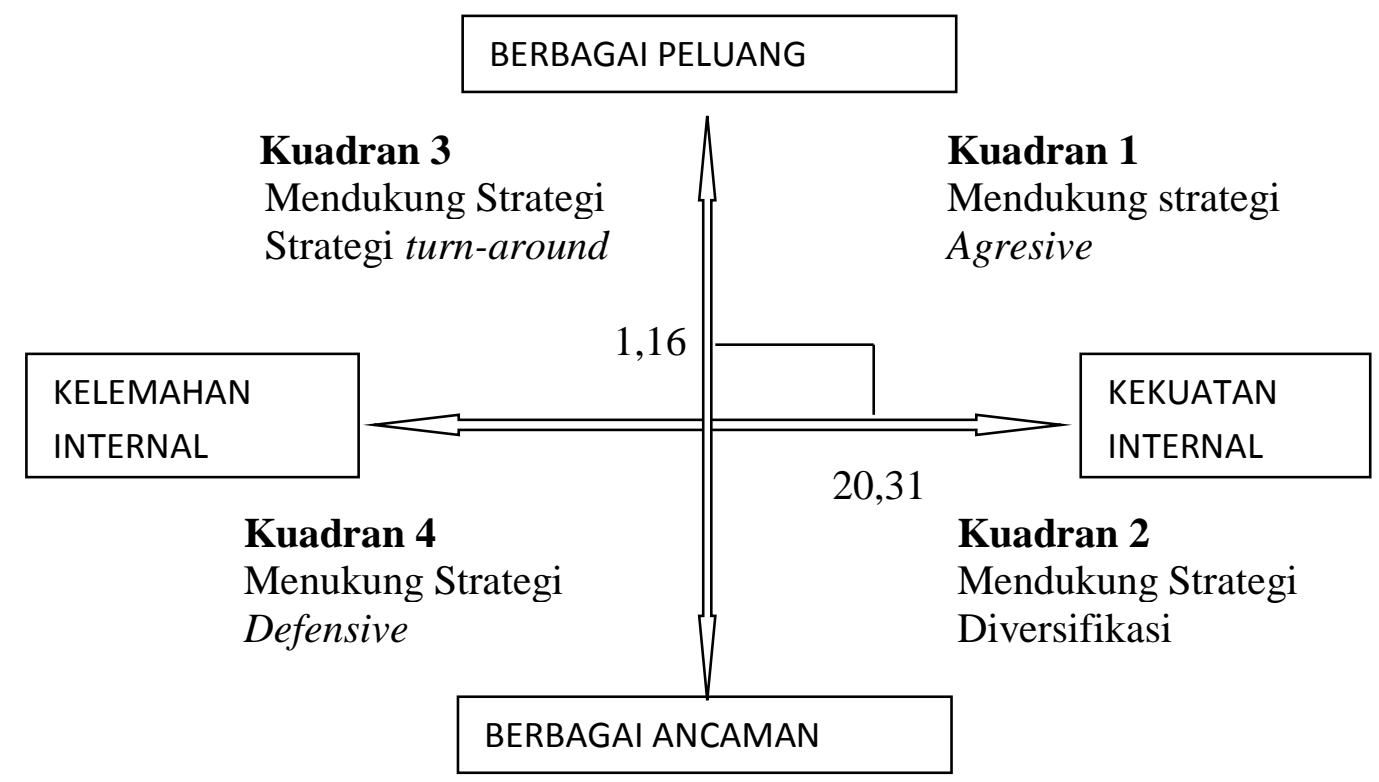

Sumber : Hasil penelitian, data diolah 2019

Diagram di atas menunjukkan titik berada pada kuadran 1 yaitu mendukung strategi agresive dalam pemasaran kosmetik Wardah di Bengkulu memiliki peluang dan kekuatan yang besar sehingga kedepan dapat memanfaatkan peluang yang ada dan strategi yang diterapkan dalam kondisi mendukung kebijakan agresive.

\section{Matriks SWOT}

Gambar. Matrix SWOT PT. Paragon Tecnology and Innovation Bengkulu.

\begin{tabular}{|c|c|c|}
\hline IFAS & Strengths (S) & Weaknesses (W) \\
\hline EFAS & $\begin{array}{l}\text { 1. Kosmetik wardah aman } \\
\text { dan berlabel halal. } \\
\text { 2. Harga produk wardah } \\
\text { sangat terjangkau. } \\
\text { 3. Mudah dicari di toko- } \\
\text { toko/mini market. } \\
\text { 4. Memiliki jaringan } \\
\text { pemasaran yang luas. } \\
\text { 5. Adanya pelayanan yang } \\
\text { didukung oleh Beauty } \\
\text { Advisor yang handal. }\end{array}$ & $\begin{array}{l}\text { 1. Kemasan yang tidak } \\
\text { bervariasi (sama). } \\
\text { 2. Produk wardah khusus } \\
\text { untuk wanita } \\
\text { 3. Distribusi produk yang } \\
\text { lama. } \\
\text { 4. Produk wardah kurang } \\
\text { dikenal masyarakat. } \\
\text { 5. Tidak ada diskon } \\
\text { penjualan. }\end{array}$ \\
\hline
\end{tabular}




\begin{tabular}{|c|c|c|}
\hline \begin{tabular}{l}
\multicolumn{1}{c}{ Threats $(\mathbf{T})$} \\
1. Banyak kosmetik \\
lain yang harganya \\
lebih murah. \\
2. Masyarakat masih \\
meragukan \\
kualitas produk \\
wardah. \\
3. Banyak salon \\
kecantikan yang \\
menawarkan \\
fasilitas yang lebih \\
lengkap. \\
4. Rendahnya daya \\
beli masyarakat. \\
5. Produk wardah \\
masih kurang \\
diminati.
\end{tabular} & \begin{tabular}{|l} 
Strategi (SO) \\
1.
\end{tabular} $\begin{array}{l}\text { Perusahaan Melakukan } \\
\text { pengembangan } \\
\text { segmentasi pasar } \\
\text { secara merata. } \\
\text { 2. } \\
\text { Melakukan penetrasi } \\
\text { harga yang bisa } \\
\text { dijangkau oleh } \\
\text { masyarakat } \\
\text { 3. }\end{array}$ & $\begin{array}{l}\text { Strategi (WO) } \\
\text { 1. Memberikan kemasan } \\
\text { yang menarik } \\
\text { mengikuti zaman untuk } \\
\text { produk Wardah. } \\
\text { 2. Beri kesempatan } \\
\text { karyawan untuk } \\
\text { pelatihan pemasaran. } \\
\text { 3. Perusahaan Harus } \\
\text { Mengikuti perkem- } \\
\text { bangan teknologi yang } \\
\text { relevan. } \\
\text { 4. Harus mengikuti } \\
\text { Sistem distribusi dan } \\
\text { pengadaan barang lebih } \\
\text { efektif dan efisien. } \\
\text { 5. Meningkatkan insentif } \\
\text { bagi karyawan yang } \\
\text { memenuhi target. } \\
\text { 6. Perlunya meningkatkan } \\
\text { kerjasama dengan } \\
\text { pihak lain. } \\
\text { Startegi (WT) }\end{array}$ \\
\hline
\end{tabular}

Sumber : Hasil Penelitian, data diolah, 2019 


\section{PEMBAHASAN}

Hasil analisis IFAS dan EFAS mengenai strategi pemasaran produk Wardah pada PT. Paragon Tecnology and Innovation Bengkulu adalah sebagai berikut :

\section{Faktor Internal}

1. Kekuatan (Strenght) yaitu kekuatan internal yang dimiliki oleh PT. Paragon Tecnology and Innovation dalam memasarkan kosmetik Wardah di Eljhon 2 Bengkulu dengan harga produk sangat terjangkau artinya dengan kekuatan yang dimiliki dapat meningkatkan penjualan kosmetik Wardah. Berdasarkan analisis IFAS strategi pemasaran kosmetik Wardah di yang dilakukan oleh PT. Paragon Tecnology and Innovation memiliki kekuatan (Strengths) sebesar 28,62 artinya dalam meningkatkan strategi pemasaran produknya dapat melakukan pengembangan segmentasi pasar secara merata, melakukan penetrasi harga yang terjangkau, meningkatkan pelayanan kepada pelanggan yang lebih baik, melakukan perluasan jaringan distribusi dan melakukan pengenal produk secara luas.

2. Kelemahan (Weaknesses) adalah kelemahan yang dimiliki PT. Paragon Tecnology and Innovation Bengkulu dalam memasarkan kosmetik Wardah di Bengkulu sebesar 8,31, ini menunjukkan bahwa kemasan kosmetik Wardah yang tidak bervariasi dan khusus untuk perempuan, pendistribusian produk lama, kurang dikenal/familier di masyarakat dan masih kurangnya program diskon penjualan produk, dari hasil perhitungan SWOT dimana nilai kelemahan (Weaknesses) sebesar 8,31. Hasil ini lebih kecil dari perhitungan SWOT dari Kekuatan (Strength) yang dimiliki oleh perusahaan.

\section{Faktor Eksternal}

Faktor eksternal yang terdiri dari peluang (Opportunities) dan ancaman (Threats) yang dimiliki PT. Paragon Tecnology and Innovation dalam memasarkan kosmetik Wardah di Bengkulu adalah sebagai berikut :

1. Peluang (Opportunities) yaitu peluang PT. Paragon Tecnology and Innovation dalam memasarkan kosmetik Wardah adalah adanya trend hijaber di kalangan masyarakat meningkat, sudah membudidaya gaya hidup untuk perawatan kulit, penduduk mayoritas muslim, produk memiliki kualitas yang baik, dan tingkat kesejahteraan masyarakat meningkat, ini berarti PT. Paragon Tecnology and Innovation Bengkulu dapat meningkatkan pemasaran kosmetik Wardah di Bengkulu yang lebih optimal. Peluang (Opportunities) dalam memasarkan produk Wardah dengan skor 17,27.

2. Ancaman (Threats) adalah ancaman yang akan dihadapi dalam memasarkan kosmetik Wardah di Bengkulu adalah maraknya penjualan kosmetik lain yang harganya masih murah, masih banyaknya masyarakat meragukan kualitas kosmetik Wardah, hadirnya salon-salon kecantikan yang menawarkan fasilitas yang lebih lengkap dan rendahnya daya beli masyarakat terhadap pelengkapan kecantikan dan kosmetik Wardah masih banyak kurang diminati oelh masyarakat/konsumen, sehingga PT. Paragon Tecnology and Innovation perlu melakukan menetapkan strategi harga yang lebih terjangkau, melakukan perubahan kemasan produk yang lebih menarik, gencar melakukan pelatihan karyawan dibidang pemasaran, mengikuti perkembangan teknologi, mengikuti 
sistem pengadaan barang yang lebih efektif dan aktif, meningkatkan kerjasama dengan pihak lain berkaitan dengan pemakaian kosmetik Wardah, Serta memberikan insentif karyawan untuk mencapai target perusahaan, dimana PT. Paragon Tecnology and Innovation memiliki tingkat ancama (Threats) dalam memasarkan losmetik Wardah di Eljhon 2 Bengkulu dengan skor 1,16 jauh lebih kecil dari skor peluang (strenght).

Berdasarkan hasil analisis SWOT terhadap strategi pemasaran kosmetik Wardah di Eljhon 2 Bengkulu dengan melakukan analisis IFAS dan EFAS, dimana strategi pemasaran produk terletak pada kuadran 1 yaitu mendukung strategi agresive dalam pemasaran kosmetik Wardah memiliki peluang dan kekuatan yang besar sehingga kedepan dapat memanfaatkan peluang yang ada dan strategi yang diterapkan dalam kondisi mendukung kebijakan agresive yaitu menggunakan kekuatan untuk memanfaatkan peluang yang ada.

Dari hasil matriks SWOT ada enam (6) strategi yang dapat menjadi pedoman PT. Paragon Tecnology and Innovation Bengkulu dalam meningkatkan strategi pemasaran kosmetik Wardah di Eljhon 2 Bengkulu yang tepat diterapkan adalah Strategi SO (Strenght Opportunity) sebagai berikut :

1. Perusahaan melakukan pengembangan segmentasi pasar secara merata, seperti ke toko-toko kecil dan pasar-pasar tradisional serta kekelompok kaum milenial yang masih ingan bergaya hidup.

2. Melakukan penetrasi harga yang bisa dijangkau oleh masyarakat seperti harga tidak melebihi harga produk yang sama dan kualitas yang sama sehingga masih terjangkau oleh lapisan masyarakat.

3. Pelayanan kepada pelanggan harus lebih baik dan ramah, seperti meningkatkan layanan ke konsumen.

4. Melakukan perluasan jaringan distribusi kosmetik Wardah, seperti membuka outlet transit di daerah yang berdekatan dengan pasar.

5. Meningkatkan distribusi produk Wardah.

6. Melakukan promosi semua kelapisan masyarakat mengenai keunggulan kosmetik Wardah.

\section{KESIMPULAN DAN SARAN \\ Kesimpulan}

Analisis SWOT yang terdiri dari kekuatan (Strengths), kelemahan (Weaknesses), peluang (Opportunity) dan Ancaman (Threats) yang digunakan oleh PT. Paragon Tecnology and Innovation Bengkulu dalam menentukan strategi pemasaran kosmetik Wardah di Eljhon 2 Bengkulu. Hasil analisis SWOT dengan menggunakan analisis IFAS dan EFAS yang dilakukan terletak pada kordinat skor $(20,31: 1,16)$ dan berada pada kuadran 1 lebih besar kekuatan dan peluang dari pada kelemahan dan ancaman yaitu mendukung strategi agresive, dimana kekuatan (strengths) senilai 28,62 kelemahan (weaknesses) senilai 18,31 peluang (opportunities) senilai 17,27 dan ancaman (threats) senilai 16,11. Kuadran 1, ini merupakan posisi yang sangat menguntungkan sehingga dapat memanfaatkan kekuatan dan peluang perusahaan secara maksimal serta diharapkan manajemen 
PT. Paragon Tecnology and Innovation Bengkulu dapat menerapkan kebijakan pertumbuhan yang agresif sehingga perusahaan boleh jalan terus dan memperbesar investasinya untuk meningkatkan keuntungan.

\section{Saran}

Hasil penelitian ini diharapkan dapat dijadikan bahan pertimbangan PT. Paragon Tecnology and Innovation Bengkulu hendaknya tetap menawarkan harga yang sesuai dengan daya beli konsumen/pelanggan, serta diiringi dengan kualitas pelayanan yang lebih ramah dan sebagai acuan untuk meningkatkan strategi pemasaran kosmetik Wardah di toko-toko/mini market yang ada provinsi Bengkulu.

\section{DAFTAR PUSTAKA}

Amirullah. 2015. Manajemen Strategi. Teori konsep dan Kinerja. Jakarta:Mitra Wahana Media,

Assauri, Sofjan. 2010. Manajemen Pemasaran:Dasar, Konsep \& Strategi. Edisi Sepuluh. Jakarta:PT. Raja Grafindo Persada.

. 2011. Manajemen Pemasaran, Dasar, Konsep dan Strategi.

Cetakan ke 11. Jakarta:PT. Raja Grafindo Persada.

David, Fred R. 2011. Strategic Management. Management Strategi Konsep, Edisi 12. Jakarta:Salemba Empat.

Erita. 2014. Strategi Pemasaran Gas Elpiji pada PT. Pagun Putra Bengkulu. Skripsi Fakultas Ekonomi Univeristas Dehasen Bengkulu:FE Unived.

Fahmi, Irham. 2013. Manajemen Strategis Teori dan Aplikasi. Bandung:Alfabeta. 2015. Manajemen Strategis Teori dan Aplikasi. Bandung:Alfabeta.

Fiki Maradona. 2017. Analisis Strategi Pemasaran pada Distro Centre Kota Bengkulu. Skripsi Fakultas Ekonomi Universitas Dehasen Bengkulu:FE Unived.

Ginting, Nembah F. 2015 Manajemen Pemasaran. Cetakan 3. Bandung:Yrama Widya

Rangkuti, Freddy. 2017. Teknik Membedah Kasus Bisnis, Analisis SWOT.Jakarta: PT. Gramedia Pustaka Utama.

Sugiyono. 2017. Metode Penelitian dan Pengembangan.Bandung:Alfabeta 